\title{
Intet hørt, intet sett
}

\author{
For noen av pasientene til Maja Husa er det faktisk slik verden fortoner seg. Husa er Norges eneste fastlege for \\ døve og døvblinde. Ved hjelp av tegnspråk, tid og tålmodighet kommer hun til bunns i de fleste helseproblemer.
}

Vår første avtale måtte avlyses på grunn av at toåringen hadde fått omgangssyke. Ved neste avtale var barnehagen stengt, men Maja og Thora tok gjerne imot besøk i en lys og luftig leilighet på Torshov. Ektemannen måtte jobbe, og mormor hadde allerede sittet barnevakt på morgenkvisten. Livet kan være en kabal når man er småbarnsmor og i fullt arbeid, men Maja Husa virker å ha evnen til å ta det som det kommer. Dessuten er hun av dem som kan gjøre flere ting på én gang. Hun snakker med barnet, varter opp med kaffe og kake og forteller om noe hun er opptatt av nemlig jobben med de døve.

\section{Lege for døve og hørende}

- Hvorfor ble du døvelege?

- Jeg har en kommunal stilling som ble opprettet for ti år siden. Stillingen er hjertebarnet til en del ildsjeler på Rådgivningskontoret for hørselshemmede, som jeg hører inn under. Det er en full stilling, og jeg har åpen liste. Stillingsbeskrivelsen går ut på at jeg er lege for døve. Jeg har foreløpig et par hundre døve og tunghørte på min fastlegeliste, resten av pasientene er hørende. Det kan jo være en glidende overgang, pasienten kan være tunghørt, og av og til er det pårørende på listen. Du trenger ikke identifisere deg som døv for å bruke meg som fastlege. - Finnes det flere døveleger?

- Jeg har den eneste døvelegestillingen i Skandinavia. De har en liknende ordning i Østerrike og i Storbritannia. I Østerrike er ordningen koblet til sykehus. Pasienten henvises dit og får en full gjennomgang der, og så sendes det epikrise til fastlegen. Vi er de eneste som har en ordning med fastlege med spesialkompetanse.

- Hvorfor trenger man døveleger?

- Det ble undersøkt hva de døve savnet mest innen helsevesenet, og det var en lege som kunne tegnspråk. Det er dessverre en kjent sak at døve får dårligere helseoppfølging enn hørende. De kommer sjeldnere til lege og lider ofte av flere sykdommer, som gjerne blir oppdaget sent. Det er dårlig kommunikasjon, de døve føler ofte at de strever med å få formidlet det de har på hjertet. Noen leger innen psykiatrien kan tegnspråk, men det fantes tidligere ingen allmennleger med den kompetansen. Jeg er den tredje på ti år som har stillingen, og jeg tar sikte på å få så god tegnspråklig kompe- tanse at jeg kan klare meg uten tolk. Det er ikke bare tegnspråket som er viktig, man må forstå en del koder og bruke nok tid. - Hvordan fungerer en tolkesamtale for døve?

- Vi er flere i rommet, ofte har pasienten med seg følge i tillegg til tolken. I en konsultasjon skal du forstå alt, det holder ikke å forstå det meste.

- Hvordan er det å snakke medisin på tegnspråk?

- Det finnes tegn for alt, så det er i prinsippet ikke vanskeligere å forklare sykdom på tegnspråk enn på vanlig norsk. I verste fall kan man lage et tegn.

- Hva er tegnet for høyt blodtrykk?

Husa viser tegnet ved å holde seg rundt overarmen. - Man lager et symbol for blodtrykksmansjetten. Tolkene kan også velge å bokstavere. Noen pasienter kan ikke norsk tegnspråk, det gjelder f.eks. mange innvandrere. Noen kan heller ikke lese og skrive. Da er utfordringen stor.

- Hvordan kommuniserer man da?

- Det er viktig å ha en god tolk, bruke mye tid og ta slike pasienter ofte inn til time. Det er faktisk ikke nødvendig å kunne lese, skrive eller kunne tegnspråk hvis begge parter prøver hardt å gjøre seg forstått.

\section{Nytt språk og nye koder}

- Du sa det også var koder utenom tegnspråket i døvemiljøet. Hva går det ut på?

- I begynnelsen syntes jeg ofte konsultasjonene kunne gå skeis uten at jeg kunne sette fingeren på hvorfor. Pasientene gjorde ikke som jeg sa, de tok ikke medisinene jeg forskrev. Etter noen år har jeg skjønt mer av hvordan jeg må gå frem for å få ønsket resultat.

- Føler du at du får sagt alt du vil si?

- Ja, det får jeg. Man kan uttrykke seg like bra på tegnspråk som på vanlig språk, det er det forsket på. Jeg kan foreløpig ikke tegnspråk godt nok, men for dem som har det som morsmål, er det er fullverdig språk. Jeg kunne ikke noe spesielt om døve før jeg begynte i jobben, men det å lære tegnspråk er spennende. Det er veldig annerledes å tilegne seg et visuelt språk.

- Hva bruker du mest tid på?

- Når en døv har vært hos spesialist og skal få orden på noe, blir det ofte mye kaos etterpå. Jeg kan ta meg ekstra god tid til å forklare hva det står i epikrisen og gå gjennom den med pasienten - og plutselig er problemet løst. Det er ganske mange døve som har diabetes. Da er det mye å passe på, du skal ha god kunnskap om både livsstil og medikamenter. De som er blitt henvist til diabetespoliklinikk, er ofte blitt verre. Så har jeg fulgt opp mer selv, brukt tolk og gitt skriftlig informasjon - uten å overdrive. Du kan ikke bare levere fra deg brosjyrer og regne med at alt går greit. Med enkle grep făr jeg bedre kontroll på diabetesen enn jeg ville hatt hvis de gikk til spesialistoppfølging. Dette har ikke noe med min kompetanse på diabetes å gjøre, men understreker hvor viktig det er med kommunikasjon og forståelse.

\section{Mer angst og depresjon}

- Du er eneste døvelege i Norge. Hvorfor ville du ha denne stillingen?

- Den var annonsert i Tidsskriftet da jeg flyttet til Oslo, og jeg syntes den virket spennende.

- Hvorfor?

- Jeg likte måten man skulle jobbe på færre pasienter og mer tid til grundig arbeid. Jeg hadde jobbet noen år i vanlig allmennpraksis og var iblant frustrert over ikke alltid å ha tid til å følge opp pasientene slik jeg ønsket. De døve er dessuten en veldig hyggelig pasientgruppe, så det var ikke vanskelig å fortsette i jobben. Jeg deler kontor med tre andre allmennleger og har en del hørende på listen, slik at jeg har variasjonen med vanlige konsultasjoner i tillegg til tolkesamtaler. Jeg får stadig flere døve på listen, og jeg samarbeider en del med døvepsykiatrien på Gaustad.

- Hva er spesielt for døve innen psykiatrien?

- Når det gjelder alvorlige psykiatriske diagnoser, ligger de døve på landsgjennomsnittet. Det de strever mer med enn hørende, er lettere psykiske lidelser, slik som angst og depresjon på grunn av sansetapet. Hvis du ikke hører, må du bruke de andre sansene i større grad. Det er vanskeligere å orientere seg i storsamfunnet. Døve bruker mye energi på å få med seg alt som skjer rundt dem. En overlege på Gaustad sa at en døv person sjelden setter seg ned i sofaen og slapper helt av. De må se rundt seg og følge med - de kan ikke høre om det kommer noen inn døren. De er mer på vakt på grunn av sansetapet. Av slike grunner har de ofte plager med stramme muskler og hodepine. 


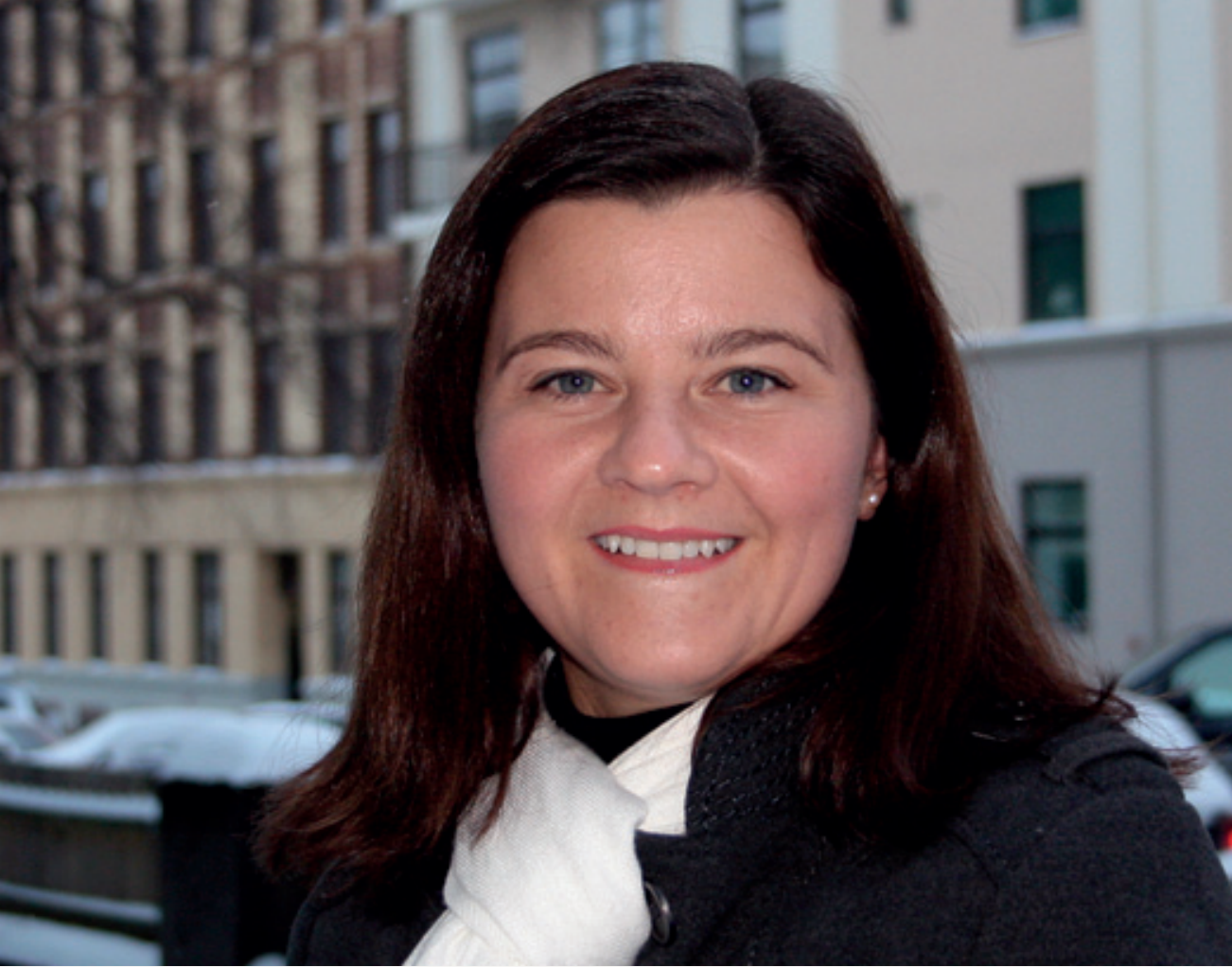

- Har det å jobbe med døve påvirket hvordan du jobber med hørende?

- Jeg tror jeg er blitt mer bevisst, og kanskje bruker jeg enklere språk i konsultasjonene. Jeg tar det ikke for gitt at pasientene forstår alt jeg sier. Informasjon kan nesten ikke formidles for enkelt, det er min erfaring.

\section{Vanskelige sykehusopphold}

- Er det noe du har oppdaget ved å jobbe med døve som har overrasket deg?

- Den døve populasjonen overrasker meg stadig. Noe av det som har forbauset meg mest, er hvor vanskelig det kan være å få døve inn på sykehus. Jeg har hatt pasienter som har vært innlagt i to uker og i etterkant ikke kan forklare hvorfor de har vært på sykehuset. De har sikkert fått informasjon, men ikke på en måte som gjorde at de forsto det som ble formidlet. Selv om det brukes tolk i sykehusene, tror jeg ikke det skjer ofte nok. Mye kommunikasjon foregår mellom visittene. Jeg er nesten litt redd når jeg henviser eller legger pasienter inn i sykehus. Bare det å få dem inn til poliklinisk time kan være vanskelig. Det som ofte skjer, er at de kommer med innkallingsbrevet fra sykehuset og ikke forstår hva det inneholder. Standardbrevet er gjerne på 3-4 sider. Det er komplisert å være syk i utgangspunktet. Det har også skjedd at en døv har sittet på venterommet hele dagen vedkommende er tydeligvis blitt ropt opp og har ikke sagt ja. Det er utrolig - når det står $i$ henvisningen at pasienten er døv. Det virker som om mange i helsevesenet ikke forstår hva det innebærer at man ikke kan høre. - Hva gjør du med dette?

- Jeg legger ved et brev når jeg henviser pasienten til spesialisthelsetjenesten, med telefonnummer til tolkesentralen og en del praktiske tips. I mer spesielle tilfeller hender det jeg ringer sykehuset for å etablere et samarbeid.

- Hvis du skulle gi andre leger et råd om døve pasienter, hva ville det gå ut på?

- Bruk tolk, men husk at tolken bare er et hjelpemiddel. Ta deg god tid, sjekk at du har forstått hva som blir sagt og at det du har sagt er forstått. Samtidig er tid noe de fleste fastleger føler de ikke har nok av. At jeg har bedre tid, er kostnadseffektivt. Jeg gjør usedvanlig mange funn og sjekker ofte litt ekstra siden døve ofte underrapporterer plager og ikke løper ned dørene på legekontoret. Det er viktig å være litt nysgjerrig. - Hva har du lyst til å få til?

- Jeg vil gjerne lære mer tegnspråk og har som mål å slutte med tolk. Jeg prøver også å få til videokommunikasjon, slik at vi kan ha tilgang til videotolk gjennom sikret linje. Jeg ønsker også samarbeide mer med fagmiljøet i Østerrike.

\section{Store og små handikap}

\section{- Du er også lege for døvblinde?}

- Det er en del mennesker som dessverre har et kombinert sansetap, blant annet på grunn av Ushers syndrom. Mange utvikler blindhet etter hvert.

- Hvordan forbereder man seg på å bli døvblind?

- Du kan lære deg taktilt tegnspråk. Det er også lurt å flytte til stedet du har tenkt å bo, slik at du kan bli kjent i området. Ellers er det viktig å vite at det finnes et eget kompetansesenter for døvblinde i Skådalen i Oslo.

- Du jobber ikke bare med døve, du er i tillegg på voldtektsmottaket ved Oslo legevakt. Det er også en litt uvanlig legestilling.

- Det ble for tre år siden opprettet en egen gruppe med bakvakter ved voldtektsmottaket. Undersøkelsene tar lang tid, og det er stadig strengere krav til sporsikring. Vi er et eget team som jobber med disse problemstillingene. En av grunnene til at de ønsket å få med meg, er nettopp at jeg jobber med døve. Dessverre er det slik at jenter med et lite handikap, for eksempel døvhet, oftere enn andre blir utsatt for seksuelle overgrep. Det er en interessant og givende jobb. Vi får

\section{Maja Husa}

\section{Født 23. mai 1977}

- Cand.med. fra Warsaw Medical University, Polen, 2003

- Lege for døve, Oslo kommune, fra 2006

- Bakvakt ved voldtektsmottaket ved Oslo legevakt fra 2007

Foto Marit Tveito

gitt dem som er blitt utsatt for overgrep en fullverdig undersøkelse og så god oppfølging som mulig. Det er et godt miljø oss kolleger imellom, vi har regelmessige kveldsmøter med faglig oppdatering. Det er mer oppfølging fra arbeidsgiver enn dersom man jobber med vanlig legevakt.

- Hvordan er arbeidet med slike problemstillinger?

- På vårt mottak har man god tid til å snakke med pasientene. På vanlig legevakt føler jeg ofte at jeg ikke får gitt nok.

\section{Privat - og veien videre}

- Hva giør du når du ikke jobber?

Husa ler, med datteren på fanget. - Etter at jeg fikk barn, har jeg måttet prioritere. Full jobb og barn fyller livet. Jeg er glad i å reise og har bodd flere år i utlandet, både i Polen og USA. Jeg liker å lære språk og å bli kjent med nye kulturer. Før gikk jeg mye på ski, jogget og fotograferte. Nå går det mest i familieliv, men det er greit det er det vi vil.

- Hva håper du å drive med etter hvert?

- Kanskje det samme som nå - det kan godt hende. Ellers er barnenevrologi et fag som interesser meg. Det er en spesialitet med mange døve og tunghørte pasienter. Først og fremst er jeg veldig fornøyd med den jobben jeg har.

- Til sist - hva føler du at du får igjen for jobben med døve?

- Det samme som andre leger, tror jeg. Folk blir friskere og får det bedre. Hvis jeg har en vellykket konsultasjon, oppdager mye og får forklart mye, er det tilfredsstillende i seg selv.

Husa er ikke redd for utfordringer. - Det er kanskje enda mer tilfredsstillende å være lege når det er ekstra vanskelig.

\section{Marit Tveito}

marit.tveito@diakonsyk.no

Vinderen DPS 